\title{
The strategies of the Spanish cotton textile companies before the Civil War: the road to longevity.
}

Fernández-Roca, Fco. Javier

\section{Introduction}

Spanish historiography has focused on studying the Spanish cotton industry rather than the companies belonging to it and has insisted on the idea that these companies were exogenously conditioned by problems such as the reduced size of the domestic market, the shortage of energy supply and a poor transport network. According to this literature, Spanish cotton companies were burdened by the increasing cost of money and forced to develop activities that were, in principle, unbecoming of them - such as marketing their products or financing the work of their commercial agents -, while suffering from the lack of financing mechanisms. ${ }^{1}$ However, issues such as the companies' structure and typology, their economic and financial strategies, the role of culture, the belief system and the institutional framework in their development or the motivation behind the decisions of business-owning families have been neglected. ${ }^{2}$

Most research works on Spanish cotton companies are elaborated from an economic history perspective rather than from a business history point of view because very few studies have yet incorporated, be it implicit or explicitly, a discipline-specific approach. Spanish literature has a precedent in the seminal work by Nadal and Ribas (1970) on the cotton textile firm La Rambla, later revised and expanded by Soler (1997). ${ }^{3}$ In this article the foundations were laid of how to study a factory, considering both its productive aspects (sales, production, machinery) and its financial ones (main aggregates and ratios). All subsequent research works have reproduced this scheme, which is more focused on the factory’s economic history than on the company's history, and have mainly analysed the period that spans from the beginning of the $19^{\text {th }}$ century to the first years of the $20^{\text {th }}$ century. ${ }^{4}$ Businessmen biographies that sometimes include information concerning their firms are also available. ${ }^{5}$ Cabana (1993) offered a compendium of biographical details on factory owners, data on their companies' history and a series of economic and financial references 
to those factories. ${ }^{6}$ Ferrer (2009) analysed the economic and financial state of the cotton textile firm La España Industrial but does not go into further details. ${ }^{7}$ The works by Prat (2008a, 2008b, 2009a and 2009b) posed questions on the companies' mechanisms to commercialise their products and finance their marketing activities and provided answers from a trade credit or industrial organisation perspective. $^{8}$

This research applies business history criteria, particularly those of the History of Family Business, because the company's configuration as a family business is decisive in order to understand the strategies implemented, the growth of the sector it belonged to or the structure of the whole industry and has more relevance in this sense than the various institutional frameworks or the varying levels of social-economic development in each country. ${ }^{9}$ This article looks at the performance of companies within the Spanish cotton textile industry and explores the financial strategies employed by them to fulfil their objectives of keeping the management of the company within the family and achieving their survival in the long term. In order to reach these objectives, Spanish companies kept unaltered the core of their financial strategy, which was based on high percentages of equity capital and low levels of indebtedness, but they managed to make it more flexible whenever the economic circumstances, as during the First World War, recommended it.

Finally, this work dismantles the negative Chandlerian vision according to which family businesses, given their characteristics, were doomed to fail in both making profits and becoming lucrative, tended to suffer short-term difficulties in order to survive in the long term and were often confronted with various conflicts whenever the next generation inherited the business from the founder (Buddenbrook syndrome) suffered from low profitability and had long-term survival problems, as even the most prosperous firms often ended up having trouble once the descendants of the firm's founder took over (Buddenbrook syndrome). ${ }^{10}$ The work focuses on long-lasting companies - ignoring all changes in their legal names and in the legal forms they adopted - whose profits were in keeping with the evolution of Spanish economy, and describes their business strategy, which was founded on four pillars: risk aversion, a high percentage of equity capital, a low 
level of indebtedness and the company's organic growth. Risk aversion arose from family ownership, which impacted on the financial policies of the firms. As a consequence they shunned loan finance and reinvested profits, thereby accumulating reserves to fund organic growth. The paper investigates the consequences of these aspects of family ownership for firm level strategy and financial performance. In particular, it investigates the extent to which accumulation of reserves facilitated vertical integration and impacted on the financial performance of the firms, as well as whether risk aversion resulted in firms achieving satisfactory profit levels consistent with long-term survival, rather than engaging in short-term profit maximisation.

From a chronological point of view, the starting point of this article is 1884, at the beginning of the last phase in the development of the cotton industry, but the research covers until the outbreak of the Spanish Civil War and is supported by the data of twelve cotton companies. ${ }^{11}$ Its first section presents the research hypothesis and the context of the family companies and places family businesses into context, explaining both their characteristics and objectives. The second section in this work examines the sources used in the research. The third section focuses on the strategy implemented by family firms, which can be considered "conservative” because it aimed to keep the company alive and under the control of the family. Once the objectives - longevity and family control - and the strategy are defined, the amount of return than can be attributed to them via profits and return on equity is calculated (fourth section). Profits underwent a period of relative stagnation between 1884 and 1936, with the exception of the First World War years, during which they reached extraordinary levels. The return on equity, on the contrary, did not show a similar behaviour, since the companies' strategy of organic growth based on their equity capital led to a strong increase of these resources after the war, badly affecting profitability. Finally, three examples of the implementation of this business strategy are provided; they all show that the companies followed the same guidelines with only some minor discrepancies.

\section{Spanish family cotton companies}


Spanish literature on the topic considers the Spanish cotton sector as a polarised structure in which a myriad of small firms surrounded a small core of large and medium-sized companies and located in an industrial district which was smaller than Lancashire. As important as the scope of the Spanish cotton sector comparatively a small one was its polarised structure, which showed a small core of medium-sized and large companies surrounded by a multitude of small firms. For instance, in 1900 the cotton spinning subsector was mostly (80.6 percent) in the hands of small enterprises with less than 5,000 spindles each, while 15.2 percent was managed by companies having between 5,000 and 10,000 spindles each and 4 percent corresponded to firms having more than 10,000 spindles each (only five of them had more than 20,000 machines). The structure of the weaving subsector was quite similar, for there were thirteen companies - each having more than 300 looms - representing 30 percent of the overall national weaving production, while the remaining 69 percent corresponded to enterprises not having more than 50 looms each. ${ }^{12}$

The Spanish cotton industry was mostly composed of firms the ownership and management of which were in the hands of one single family. ${ }^{13}$ To study the reality of a sector based on family enterprises entails, first of all, a debate on the very concept of family business. This debate is still alive in current business history literature and, consequently, there is no universally-accepted definition of the term. ${ }^{14}$ In an attempt to offer one, some business historians have focused on property and/or the management of the firm by certain family members. Others have defined the concept in relation to the degree in which the family is involved in the business and to the actual possibility of transferring the business to the next generation. Other historians have considered the percentage of capital under family control. There are more complex approaches that connect different aspects of the company's reality in an attempt to reach a proper definition. A broad definition would entail the family's retention of voting control over the strategic direction of the firm; a medium range definition would consider the family's retention of voting control plus the direct involvement of the family in day-to-day operations; and a narrow definition would require the family's retention of voting control over the business and the involvement of multiple 
generations of family members in the company's daily operations. Business historians generally take the following three aspects into account in their studies: percentage of capital under family control, family control of the company's management and intergenerational transfer of the business. With regard to this article, the definition that best suits the Spanish entrepreneurial framework while encompassing these three aspects is the one provided by Colli and Rose (2007: 194), ${ }^{15}$ according to which a family business is one in which a family owns enough equity to be able to exert control over the company’s strategy while having at least two generations of family members involved in the top management positions of the firm.

Second, the goals of family companies need to be specified. In general, family firms have two commonly accepted aims: to guarantee the survival of the firm and, therefore, allow its transmission to the next generation, and to keep it under the control of the family. The objective of maximising profits is subordinated to these first two aims. The first objective, the company's longevity, is related to the fact that family firms invest a percentage of the family assets in the development of the business, sometimes even all of it, thus compromising the economic stability of the family. This is the reason why the company must, in the first place, achieve longevity as a mechanism to guarantee the preservation of the family assets; bankruptcy would bring ruin to the family.

Third, all family firms are not equal and it is possible to differentiate dynastic family companies (a high percentage of family ownership and control) from non-dynastic family companies (a lower percentage of family ownership, not all management positions under the control of the family). ${ }^{16}$ Within the Spanish cotton industry, family companies with a significant dynastic component that emphasized their family business character were predominant. ${ }^{17}$ Despite an implicit belief in the loyalty of the next generation, founders often exhibited a highly personal, autocratic style of leadership, which indicated a lack of trust in the future. However, it was their offspring, trained extensively for the task, who in the end inherited the company rather than outside professional managers. The introduction of the dynastic component meant that the founder 
conceived the business as a good that he aimed to preserve intact and transmit to subsequent generations. These future generations were understood as steps along the stairway of inheritance and were held responsible for perpetuating the company and possibly expanding it without substantially modifying its nature. Dynastic family companies demanded intergenerational loyalty in order to guarantee the intergenerational transfer of the firm. The fear of inefficient management led the founder to retain control of the company longer than it was actually required, so that the heirs took over the management later in their professional lives when they had accrued the human capital, age and experience considered essential for the correct guidance of the firm. As tradition wanted it, not only the family's name needed to be upheld, but the business methods as well. ${ }^{18}$ The business culture of the firms here considered consisted of a set of values that were passed from generation to generation and completely internalised by the family owners, making far-reaching change difficult. Family business culture was therefore less elastic than the wider changes taking place in society, and placed restrictions on potential activity areas that could have represented a solution to the challenges posed by increasing foreign competition. ${ }^{19}$

In a context of "personal capitalism" as the Spanish one at the end of the $19^{\text {th }}$ century and during the first third of the $20^{\text {th }}$ century, companies are understood in personal terms rather than in economic ones and are seen as goods to be preserved for the heirs; in this context, profit, equity reserves and capital accumulation cannot be ignored. ${ }^{20}$ Our hypothesis considers a family business as characterised by risk aversion. Risk aversion would even stop the undertaking of activities that fell out of the path traditionally marked by the founder to guarantee the company's survival and consequently the family's wellbeing - company and family thus standing as synonyms. ${ }^{21}$ Risk aversion was also directly related with the objectives of longevity, i.e. of guaranteeing the intergenerational transmission of the company, and family control. With the aim of reaching the above mentioned objectives, Spanish cotton-producing families chose a financial strategy for their businesses that was based on the important weight of their equity capital and on the maintenance a low level of indebtedness. 
In this respect, Spanish historiography usually takes two different stances. The more traditional perspective maintains that the family companies' decision not to resort to debt capital, except in small percentages, and to focus instead on their equity capital may have been reinforced by the economic framework within which they developed. Again, the literature on the topic insists on that Spanish cotton manufacturers, as compared to their British colleagues, were forced to assume the costs of financing the work of textile merchants, especially the Southern ones, so that in the end they became factory owners, merchants and bankers at the same time and their profitability consequently suffered from it. Two factors were responsible for the multifaceted condition of Spanish cotton businessmen: on the one hand, the country's general backwardness - Spain was an agrarian, poor country with low levels of consumption - and, on the other, the lack of enough trading and financial institutions. ${ }^{22}$ A clear example of this situation was the case of Berenguer $y$ Cía., which was a net creditor (the difference between its debtors and creditors was always positive) but acted as a bank for its clients by using its excess liquidity. ${ }^{23}$

According to a new approach, European cotton industries showed a similar behaviour to that of the Spanish cotton sector. Processes aimed to vertically integrate production and marketing activities coexisted in them with the firms' collaboration with great distribution and sales companies. $^{24}$ In other words, the Spanish case was not anomalous within the European context, while Lancashire industrial district was in fact exceptional insofar as production and marketing were never vertically integrated by the companies established there. ${ }^{25}$ In addition, Spanish economic backwardness was not the only factor to explain the adoption of marketing mechanisms by the national cotton industry: the lesser size of the industrial district was also decisive of the manufacturers' essential role in the process of commercialising their products. ${ }^{26}$ Finally, Spanish businessmen knew how to use their commercial network in order to promptly detect changes in the demand. Prat states that "manufacturers built their own commercial structures because they needed to have a foothold close to consumers, but not because of a lack of merchants”. ${ }^{27}$ 
The decision to guarantee both the companies' stability and longevity postponed the maximisation of their profits and profitability. Nadal clearly expressed it (1988:45) when he discussed the characteristics of La Rambla's managers:

“Els socis d'una companyia industrial han d'oblidarse del que més tard s'ha anomenat la 'maximització del benefici' i fer una aposta de futur. Durar llarg és més important que guanyar diners."

("The partners of an industrial company need to forget about what later on will be called "profit maximising” and invest in the company’s future. Lasting is more important than making money.") $)^{28}$

This perspective on business was typical not only of dynastic family companies, many of which were still bound by unlimited liability or had only recently been transformed into public limited companies. The case of La España Industrial, a family firm created as a public limited company and quoted on the stock market, is very significant. Its chairman, J.A. Muntadas, who may have been under greater pressure than other businessmen to achieve the profitability and dividends required to maintain the value of the shares, expressed himself in the following terms:

"Séame lícito añadiros, que el verdadero industrial, trabaja y se afana por algo más que por la remuneración de sus capitales. Ama el industrial su industria, con el propio entusiasmo que el artista su arte, que el literato la literatura". ${ }^{29}$

("Let me add that a genuine industrialist works hard for something more than increasing his capital. He loves its industry with the same enthusiasm as an artist loves his art and a writer loves literature.”)

In addition, the companies were the main source of stability in what concerns the income and wellbeing of business-owning families. ${ }^{30}$ Family revenues came from the salaries earned by the company's managers, from the percentage of profits due - according to the company's Articles of Association - to those family members who held a position in the board of directors and, finally, from the interests accrued on the interest-bearing accounts that they had in the company. Thus, the family, who controlled the management of the firm, was interested in preserving the company and guaranteeing its longevity rather than in risking strategies that could generate high profits in the short-term but also weaken the company's financial situation in the longer term. ${ }^{31}$ This conservative behaviour was relatively comfortable and easy to defend because few were the shareholders - or 
partners in non-public limited companies - to whom the company was accountable, and most of them belonged to the family. ${ }^{32}$

The strategy aiming to guarantee the firm's longevity was applied during the whole period analysed here, independently from the legal form adopted by the company. ${ }^{33}$ Operating as unlimited liability entities, business-owning families, for which the boundary between company and family was blurred, lived under a permanent threat of bankruptcy. ${ }^{34}$ In Spain, two were the legal forms generally preferred when founding a company: most businesses were general partnerships (constituted by a small number of partners whose assets were subject to the principle of unlimited liability through short-term contracts that could be extendable depending on the evolution of the firm) and the rest, to a much lesser extent, were limited partnerships (with one or more general partners who operated under the principle of unlimited liability and one or more limited partners who were only accountable for whatever amount they had contributed to the firm). Limited partnerships were constituted only when there was a need to mobilise great amounts of capital. ${ }^{35}$

It took the Spanish cotton producers some time to transform their businesses into public limited companies despite the changes introduced in Spanish commercial laws (1829, 1848, 1865 and 1885), meant to facilitate the incorporation of this legal form. ${ }^{36}$ It is true that, pushing in the other direction, fiscal policies had favoured the transference of the company within the family by including exceptions "for wealth transmitted to kinship in first degree (descendants)" in the Impuesto de Derechos Reales (Inheritance Tax, 1982). ${ }^{37}$ However, Spanish cotton firms (without losing any of their family essence) became public limited companies after the First World War. ${ }^{38}$ And in spite of it, when the Catalan textile businesses became public limited companies in the 1920s, their strategic behaviour remained the same, since the families still linked a significant percentage of their wealth to the development of their firms. ${ }^{39}$

Finally, the contributions made by research works with firm accountability, scale and scope perspective are also considered. ${ }^{40}$ From this point of view, Spanish cotton textile companies moved within approximately the same parameters as British firms. They all concentrated capital ownership 
in the hands of a clique of directors and most of the firms belonged to the same social networks and employers associations. ${ }^{41}$ In Catalonia, where most Spanish cotton companies were concentrated, as in Lancashire, these amalgamations exploited external economies of scope, involving little expansion of scale at plant level or integration of the production system. As Toms and Wilson (2003: 11) concluded, "this meant that where businesses did increase in size, they generally did se without diluting control to outside stakeholders".

This section has shown how the Spanish cotton sector was mostly formed by small and medium-sized family companies, where the families held control of the management and retained a significant part of the business for at least two generations. Longevity and control were the main objectives and, in order to achieve them, the families preserved the dynastic character of the companies' values, business methods and culture and put stability before profit maximisation their business strategies were always conservative, independently from the companies' legal form. After describing the structure of the Spanish cotton sector and the characteristics and objectives of the companies belonging to it, the next section will analyse their business strategies with further detail.

\section{Sources and accounting methodology}

The sources that support this research are the balance sheets of twelve Spanish cotton companies Forcada, Sedó, Fabra, Valls, Viladomiu, Güell, Mata, Serra i Feliu, Almeda, La España Industrial, Berenguer i Cía. and La Rambla. The sources from where the data were taken are diverse. The data of La España Industrial were taken from Cabana (2001) and Ribas (1999); Cabana (2001) also provided those of Fabra. ${ }^{42}$ The data of La Rambla were found in Nadal and Ribas (1970) and Soler (1997). ${ }^{43}$ The balances of Berenguer i Cía. were first published by Ferrer (2009). ${ }^{44}$ The accounts of Forcada, Sedó, Fabra, Valls, Viladomiu, Mata, Serra i Feliu and Almeda were consulted at the Arxiu Nacional de Catalunya (National Archive of Catalonia). ${ }^{45}$ Finally, those of Colonia Güell were collected at the Arxiu Historic Comarcal de Manresa (Historical Local Archive of Manresa). ${ }^{46}$ 
A question that may arise is whether these companies are representative of the universe of small and medium-sized cotton textile companies operating in Spain and, more specifically, in Catalonia. Even if the number of companies analysed here is small, it is considered to be representative of the cotton sector because it combines both large and small enterprises - including some of the most important Spanish textile companies (La España Industrial) -, dynastic and nondynastic family businesses, unlimited liability firms and public limited companies quoted on the stock market. And, in all cases, at least three generations of the same family succeeded each other at the head of the company. ${ }^{47}$

Regarding the analysis of the balance sheets, the methodology applied is the one designed by the Central Balance Sheet Data Office of the Bank of Spain. For each firm, the balances have been standardised by synthesizing them and reducing their data to the main asset (fixed and current) and liability entries (equity capital, long-term debt, short-term debt with financial cost and shortterm debt with no financial cost). Amortisations with a minus sign are reported as part of the fixed assets entry, even if most of the companies had already subtracted them from their fixed assets. To calculate the company's equity capital the company’s capital, its equity reserves, provisions and annual retained earnings have been added up, and its retained losses have been subtracted. ${ }^{48}$

The ratios used to show the degree of risk aversion are the percentage of equity capital to total resources and the ratio of indebtedness. The latter was calculated by simply adding up all liabilities (long-term and short-term debt, with and without financial costs) and dividing the final amount by the totality of equity capital. ${ }^{49}$ A complementary ratio was also taken into consideration: the ratio of indebtedness once the amounts lent by the owners and their families to the companies are deducted. In other words, current accounts and loans granted by the family owners were subtracted from the company's long and short-term debts, with and without costs. The result was divided by the total amount of the company's equity capital. Financial leverage is not incorporated into indebtedness because the information provided by the companies' balance sheets includes neither earnings before interests and taxes nor earnings before taxes. 
In this work, the behaviour of the return on equity is studied (hereinafter, return on equity and profitability are used as synonyms). ${ }^{50}$ This ratio was chosen because, first of all, it allows measuring the return on investment obtained by business-owning families, an indicator that can be calculated by dividing net distributable profits after interests and taxes by the company's equity capital, which, instead of being distributed as dividends, are accumulated by the firm. In the second place, the return on equity is used because, as mentioned before, our sources do not provide any data on earnings before interests and taxes, and, therefore, economic profitability cannot be calculated. The third reason for using this ratio is that both Spanish literature on cotton companies and literature focused on the study of business profits use as well these two indicators (net profits and return on equity), thus making it easy to compare cotton companies with the country's overall industrial framework. $^{51}$

The information missing in the different sources leaves us with some gaps that are almost impossible to fill, but that do not affect the main hypotheses of this article. Thus, although it is known that the companies had low levels of indebtedness (low financial leverage), the degree to which their return on equity was conditioned cannot be estimated since data are lacking on whether the ratios of economic profitability were above the cost of the debt. Theoretically, a high level of financial leverage is tolerable when the company enjoys high economic profitability. However, the companies under study belonged to a mature and "very crowded" sector where profits were not especially high and the profit/assets ratio was probably below the interest rate. This reality reinforced the argument that led the companies to resort to self-financing and fund their activities with their equity capital. Was it worth getting into debt and risking the viability of the company if profits were not high enough to meet loan obligations? Obviously, the families preferred to guarantee the longevity of their firms over taking unnecessary risks. In fact, as seen below, in periods of high profits (during the First World War) the companies increased their level of shortterm indebtedness, since they felt more able to meet the repayment of the commercial loans asked for. In general, self-financing their companies with their equity capital seemed a correct strategy for 
a mature sector with minimum barriers to entry. For even if financial leverage might increase the profit, this might not compensate the risk of losing the company. Under normal circumstances, this was probably the most rational option for a low-profit Spanish cotton industry.

Finally, the series of data presented under each family's last name are the outcome of the activity of the consecutive business entities created by each family under different legal names and forms. In those times, business assets operated under the protection of legal forms that were created and dissolved according to the family's circumstances and, more specifically, to the specific moment in the life of the company's founder. Generally speaking, the companies were transformed from general partnerships into limited partnerships before finally becoming public limited companies. Certain small discrepancies may be perceived in the process of linking the data of two consecutive companies belonging to the same family, especially when trying to match the final balance sheet of one company with the initial inventory of the following. For instance, the strong fluctuations of the companies' equity capital (Valls and Berenguer) were due to the successive company changes within the family business because, at the time of a firm's liquidation, the partners distributed a percentage of the retained earnings that had been accumulated as part of the company’s equity capital (usually under the heading of "capital”). Thus, the newly founded firm began its activity having a smaller amount of equity capital than the recently liquidated company, with the compensation of an increment of indebtedness. ${ }^{52}$ In cases such as those of Serra and Berenguer, the company's equity capital was calculated by adding up the paid-up capital and the partners' accounts in the company, given that the retained earnings were kept in those accounts. For instance, in 1917 Serra's paid-up capital increased from 335,000 to 1.3 million pesetas. This amount matched the one that had been accumulated in the partners' accounts as part of the firm's liabilities. That year the family accounts disappeared from the company’s balance sheet.

\section{The strategy: risk aversion and low indebtedness}

In order to guarantee the survival of their companies, Spanish cotton producers at the end of the $19^{\text {th }}$ century and during the first third of the $20^{\text {th }}$ century, continued to apply the old financial 
strategy based on the relevance of the company's equity capital and a low level of indebtedness. Figure 1 reflects the evolution of the companies' average percentage of equity capital to total liabilities in Spanish firms and how equity capital constantly represented 60 to 80 percent of the companies' total balance from 1884 to 1935. This high percentage of equity capital in Spanish companies was destined to provide the firms with enough financial strength to face negative economic cycles and to enjoy a wide margin of financial autonomy. ${ }^{53}$

\section{Figure 1. Average percentage of equity capital to total assets in Spanish companies}

Generally speaking, family enterprises - and cotton firms were no exception in this sense were reluctant to external financing, both in the long and the short term. ${ }^{54}$ Spanish cotton companies differed from their European counterparts, not in the use of their equity capital, but in the intensity of that use, because Spanish firms used their equity capital not only to finance their fixed assets and most of their current assets, especially their own clients but also, in many cases, their current liabilities and even their particular trade creditors. ${ }^{55}$ Thus, the percentage of financing from external sources required by Spanish cotton companies was low and, as shown below, was concentrated in short-term liabilities.

The concept of debt capital in the case of Spanish cotton textile companies deserves to be clarified since not all of that capital actually derived from external sources. First of all, a very high percentage of it came from the current accounts that the owning families had in their companies. These were often interest-bearing current accounts (at a 3 to 5 percent rate) and served to face shortterm financing needs. Second, if the companies required financing in the medium or long term they, in the first place, applied for the loans that the partners themselves could offer and, as a second option, looked for funds within the social network of business-owning families. ${ }^{56}$ Thanks to this double option, Spanish cotton textile companies, like their British counterparts years before, covered a very high percentage of their short-term financing needs with family funds, thus eluding the financing system. ${ }^{57}$ Banks were only used to provide the necessary mechanisms for international 
operations; with this aim, the companies opened sight accounts in foreign currencies, and some of them even did it in foreign banks. ${ }^{58}$

\section{Figure 2. Ratios of indebtedness}

Figure 2 reflects the ratio of indebtedness and the ratio of indebtedness once the partners' accounts are deducted. Generally speaking, both ratios show that the companies had a low level of indebtedness, something predictable given the preponderance of equity capital, and show as well how the level rose during the expansive phases of the cotton sector: the years prior to the 1898 war and the 1914-1920 period. Once the resources of partners and families are deducted, the ratio of indebtedness connects with the hypothesis suggested by Tafunell (1998b). ${ }^{59}$ This hypothesis stated that the reduction in the activity of Catalan financial entities was partly due to the fact that their services were rarely used by business companies. The consumption goods industry and, within it, the cotton industry were indeed particularly reluctant to resort to these financial institutions.

The results of the ratio of indebtedness for the 1900-1906 period are upwardly distorted because it was only possible to include six firms (four in the 1903-1904 period) in the calculation. In those years, the percentage represented by Serra - the most indebted firm (0.83) - dragged the average upwards, and thus this period seems the phase with higher business indebtedness. However, Annexe 1 shows that the other companies - Almeda (0.13), Berenguer (0.21) and Sedó (0.37) - had a much lower ratio of indebtedness during those years; therefore, the main hypothesis - the low level of indebtedness of Spanish cotton companies - remains valid. Furthermore, the low and stable ratio of indebtedness once the partners’ accounts are deducted confirms this hypothesis. ${ }^{60}$

During the First World War and the immediate post-war period, the orthodox financial strategy applied until recently enjoyed a flexibility that was unknown to the Spanish cotton business culture. Through the war years, the companies increased their levels of production and marketing activities, profiting from the opening of the international markets - hardly accessible before - and from the vanishing of a great number of foreign competitors; however, they had to confront the difficulties associated to shortages in the supply of raw materials and intermediate inputs, and to 
constant risks in transportation. ${ }^{61}$ The commercial expansion of the cotton industry was based on exports, which rose from an average of 6 thousand tons in 1910-1914 to an average of 16 thousand tons in 1915-1919. In other words, cotton exports increased by an annual average of 2.5 percent, and 70 percent of them had Europe as their final destination. ${ }^{62}$

To meet the needs of a more intense industrial activity, a greater volume of raw materials, stocked products, commercial operations, etc. was required. The companies saw how their demand of current assets increased. ${ }^{63}$ The new - strictly commercial - financing needs in the short term led businessmen to apply a temporary strategy that resorted to debt capital in order to face those needs, but with the peace of mind of knowing they had the backing of rising profits (Table 1) allowing them to meet loan obligations. Their decisions led to a reduction of the percentage of the firms' equity capital, which, in some cases, dropped 40 percent, reaching overall minimum levels in all cases, while a parallel increment of the ratios of indebtedness (Figure 2), which reached their maximum values, was taking place. However, financial stability was in no case put at risk. ${ }^{64}$ It was during the last war years and the post-war period when the companies were most indebted, their ratios reaching an average of 0.62 and 0.65 in 1919 and 1920, respectively. Most companies present their maximum ratios in that period, as in the case of Sedó (1.17 in 1918 and 1.15 in 1919), Valls (1.29 in 1919 and 2.59 in 1920), or Forcada $\left(1.36\right.$ in 1921). ${ }^{65}$ Nevertheless, the ratios of indebtedness decrease considerably if the financing from the families, which represented a very relevant percentage of the companies’ financing, is deducted. Sedó’s ratio was thus 0.69 in 1918 and 1919, Valls’ 1.29 in 1919 and 1.84 in 1920 and Forcada’s $0.47 .{ }^{66}$

The companies understood the end of the First World War and the post-war period as the right moment to invest in new installations and machinery (fixed assets), by way of organically financing them with their equity capital. ${ }^{67}$ In general, most firms behaved the way Nadal (1998:77) explained in his description of the Sedó family business. ${ }^{68}$ The companies’ expansion was financed without actually questioning the orthodox philosophy of the family business: the company’s equity capital was increased, most often by expanding the capital subscribed by the owning family. Ribas 
(1999: 1.132) showed that La España Industrial operated in a similar way and financed the modernisation of its business and financial structures with the non-distributed profits accumulated since 1919. ${ }^{69}$ There were some extreme cases such as that of Berenguer y Cía., which in the 1920s financed its investments with its equity capital, profiting from its position as creditor. ${ }^{70}$ At the end of that decade, most companies’ equity capital had recovered their pre-war percentage rates and their ratio of indebtedness had become almost irrelevant. ${ }^{71}$

It is worth pointing out that on quite a few balance sheets the companies' payable debt appeared to be zero (Annexe 2). The structure of the debt is also worth examining. It was mostly short-term debt, long-term debts being contracted on very few occasions. For instance, Forcada, Viladomiu and Berenguer did not recur to long-term indebtedness at all. Mata and Sedó did it only in the first years after their constitution as general partnerships. Valls and Güell (Figure 3), which accumulated the greatest percentages of long-term debt, were an exception. In the successive companies owned by the Valls family, long-term financing was a resource used only in the years immediately following a change in their name or legal form. Each of Valls' firms was, at the beginning, heavily financed with long-term debt capital, but the proportion of long-term debt diminished at the same pace the company's equity capital incremented. As for Colonia Güell S.A., it was one of the quoted companies on the Barcelona stock market. The firm was founded in 1920 with an initial capital of 3.5 million pesetas and the same amount in shares within the portfolio (receivable). In 1924, the company's capital had reached the amount of 12 million pesetas complemented by an issuance of long-term mortgage-backed bonds with a value of 6.5 million pesetas. In 1935, the financing was completed with a mortgage loan worth 0.5 million pesetas. This capital was destined to cover the investments in machinery and new buildings made by the company in the mid-1920s, just at the end of the expansive cycle provoked by the outbreak of the First World War. Colonia Güell S.A. accumulated the greatest long-term debt and its achievements were limited by the distribution of low dividends until 1933.

Figure 3. Structure of debt capital in the companies owned by the Valls and Güell families 


\section{The consequences of the strategy: profits and profitability}

With this conservative mentality manifested through the double objective of "preserving" both the company in the long term and the family's control over it, the decision to maintain a high percentage of equity capital in order to guarantee financial stability had a direct effect on the return on equity. The return on equity can be calculated by dividing the company's net distributable profits after interests and taxes by its equity capital. Any increase of the company's equity capital resulted in a decrease of its return on equity, unless profits grew at the same pace. In general, a high percentage of equity capital represents a heavy weight on the firm's return on equity. ${ }^{72}$ The fact that there is a close relation between equity capital, profits and return on equity makes it not only relevant to know how the return on equity behaved but mandatory to observe how business profits evolved. $^{73}$

\section{Table 1. Profits of the Spanish cotton companies (millions of 1995 current pesetas)}

Profits expressed in constant pesetas reflect the companies’ revenues in real terms and eliminates extreme peaks originated by uncontrolled rises in the prices (as during the First World War). The data can be chronologically distributed into four phases. ${ }^{74}$ During the first phase, covering until 1890, profits were moderate due to the impact of the first Cuban insurrection and the fin-de-siècle crisis; the companies suffered from an accumulation of conflicts. Three public limited companies disappeared in those years: La Industrial Cotonera (1877), La Igualadina Cotonera (1880) and, a few years later, La Fabril (1892). The idea that other strategies, different from the one described here, must have caused their extinction can be put forth. Specialised literature generalises the situation of the larger companies to the whole cotton textile sector: "ja que molts altres de m'es petites dedicades tamb'e als filtas i teixits de cotó a les mateixes poblacions de Reus, Igualada, Vic o Barcelona patiren mals semblats" ("since many others, smaller ones, specialised as well in cotton spinning and weaving in the towns of Reus, Igualada, Vic or Barcelona suffered from similar troubles"). ${ }^{75}$ However, it is very likely that the financial structure of the smaller companies resembled the one described in this work, a fact that may have been enough for them to survive. 
The second phase started with the implementation of protectionist policies by the Spanish government and it seemed to announce a bright future for cotton textile companies. These companies immediately began to rely upon the protectionist measures applied to the domestic market and upon their exclusive rights in the colonial market. ${ }^{76}$ Nevertheless, profits first decreased and then stagnated due to several factors. Activity in this period was soon weighed down by the second colonial insurrection (1895-96), the war against the United States of America and the loss of the colonies in 1898 which coincided with an agrarian crisis at the turn of the century. Production costs were mounting (raw materials and energy), the price of manufactured products escalated and export difficulties increased. ${ }^{77}$ The industrial sector tried to defend itself in a saturated domestic market - characterised by the contraction and inflexibility of the demand - by taking advantage of the protectionist policies introduced by the Spanish government. However, in the case of cotton products, these measures did not translate into higher prices that would have allowed greater profits because small and medium-sized cotton companies developed their activities within a competition regime. $^{78}$

The third phase comprises the years during the First World War and the immediate post-war period. In those years, profits greatly increased thanks to a strong export expansion (supra) linked to the advantages that a world at war offered to the cotton textile industry. ${ }^{79}$ The extraordinary profits grew progressively from 1914 onwards and reached a peak in 1922.

The fourth and final phase lasted until the outbreak of the Spanish Civil War (1936) and showed a trend leading to profit stagnation at almost pre-First World War levels. Once this war was over, both the factors that favoured the industry and the problems that affected it reappeared with greater intensity: excess capacity, falling prices, increasing world production, growing competition of man-made fibres, difficulties caused by competition in the international market. ${ }^{80}$ The Cambó Tariff (1922) represented a turning of the screw for Spanish protectionism, but it proved insufficient to safeguard the industry's interests. In addition, the crisis of the 1930s pushed the sector against the 
wall. ${ }^{81}$ In 1930, the Comité Regulador de la Industria Algodonera (Regulation Committee of the Cotton Industry) described the situation as follows:

"El malestar de nuestra industria algodonera obedece en parte al natural reflejo de la crisis general que afecta a dicha industria. Descienden los precios de las manufacturas y se estrechan los márgenes con respecto a las materias primas además del exceso de producción" 82

("The unease of our cotton industry is partly a natural reflection of the general crisis affecting the industry. Manufacture prices decrease and margins are narrowed in relation to raw materials, and there is, in addition, an excess of production.”)

Spanish literature on the topic states that occasional upturns in this period, especially in the 1930s, were related to a modest reactivation of the domestic demand connected to a favourable agrarian situation in specific years (1932 and 1934) and to the improvement of real salaries during the period of the Spanish Second Republic. It also insists that the growth of production until 1935 proves that the sector's pessimistic view was unjustified. ${ }^{83}$ However, the increment of production does not mean that profits increased in the same proportion. Profits showed a high annual volatility and a great dispersion between companies, but it did not break the decreasing trend that was evident since 1922. Finally, Spain’s growing political instability hindered profit recovery and contributed to the losses suffered by some of the companies after 1934 .

Figure 4. Return on equity of the cotton sector and the consumption goods industries

The return on equity of the cotton industry behaved similarly to its profits; its values were below those of profits only since the mid-1920s. Figure 5 reinforces the commonly accepted vision according to which the profitability of the cotton sector was lower than that of the whole Spanish industry. Between 1884 and 1935, few were the years in which the cotton sector was triumphant when compared to other national consumption goods industries. The years previous to the second Cuban insurrection and the subsequent war against the United States were an exception. Profitability reached a peak of 14 percent in 1892, but thenceforth the decline was evident until it hit a low in 1900. A long lethargic period started then that lasted until 1914 during which profitability remained at a 5 percent level. ${ }^{84}$ The First World War, as previously mentioned, opened 
an extraordinary phase in the growth of Spanish industrial profitability, particularly in the case of the cotton industry. However, the spectacular results achieved in this sector in the year 1922 represented a real swan song. The strong reduction of profitability after 1923 is related to two factors meeting in time. On the one hand, the period of extraordinary profits stimulated by the war and the dislocation of the world markets had come to an end; on the other hand, the companies started a process of financial reinforcement based on the increase of their equity capital in order to generate enough reserves to overcome the profit fall - including losses - during the 1930s (supra). ${ }^{85}$ Differences can be pointed out between Spanish, British and Italian family firms, all of them worried to strengthen financially, and the public limited companies of the Oldham district, which applied a profit distribution policy that led to their final decapitalisation. ${ }^{86}$

Spanish financial results show some discrepancies with the British results at the chronological level, all of which are caused by the exposure of the sector to the particular commercial cycle of each country. Thus, while Spanish companies underwent a quite positive phase before the outbreak of the colonial war and then became lethargic until the First World War started, British firms experienced exactly the opposite. Nevertheless, data from the post-war boom and slump period show an almost identical evolution in both countries. ${ }^{87}$ Table 1 summarises the return on equity data of Spanish cotton companies. It is unnecessary to analyse the details here; it will be enough to point out how some of these companies achieved impressive return on equity rates between 1914 and 1922 - reaching peaks of 50 percent (Güell in 1922) - and how the period of prosperity during the war was followed by years of decaying return on equity - the values were negative after 1934 - due mostly to a strong increase of the ratio’s denominator, the companies' equity capital.

Table 2. Return on equity of the Spanish cotton companies and average return on equity of the cotton sector and the consumption goods industries

\section{Three relevant cases of financial strategy}

The following examples prove how financial strategies determined the behaviour of profitability. Figures 5, 6 and 7 reflect the evolution of each company's equity capital, profits in 
constant pesetas and profitability in three different cases: La España Industrial, Sedó and Valls. Each of them has its own interesting particularity. La España Industrial was the only cotton company, of the ones here analysed, that, being a family firm, had not a dynastic component; it was soon transformed into a public limited company that was quoted on the stock market during the whole period studied. Both Sedó and Valls were family firms with a dynastic component that maintained their original characteristics even when they were transformed into public limited companies after the First World War. The difference between them lies in that Sedó operated almost without any long-term payable debt and Valls was the company with the greatest percentage of long-term payable debt.

\section{Figure 5. La España Industrial}

The strategy of La España Industrial is absolutely clear. Even if the company was quoted on the stock market, it still preserved the characteristics of a non-dynastic family business: the Muntadas family kept a relevant percentage of the business' shares and members of several generations occupied management positions at the head of the company. The company's investments, modernisation and growth permanently depended on its equity capital. ${ }^{88}$ Profits in absolute terms remained stable between 1884 and 1914, exception made of a peak before the second Cuban insurrection. Steady profits and a lack of expansion of the company's equity capital helped stabilise the return on equity at 6 percent, a ratio that was a bit higher than the ROCE enjoyed by Fielden Brothers Ltd. $^{89}$

In relation to the companies' objective to guarantee their longevity, it is possible to point out a relevant strategic difference between a family firm and one that is not, even when both are public limited companies. For instance, the managers of Osborne, a closed private company and one of the Oldham Limiteds, chose to distribute dividends - instead of capitalising the company and reinvesting in new technologies - not only because that was the shareholders' wish but also to increase their own revenues. The shareholders of Werneth, an open public company in the same district, were more interested in compensating the risks that had been taken by distributing 
dividends. ${ }^{90}$ La España Industrial, in opposition, implemented a dividend distribution strategy with the objective of preserving its financial solidness; consequently, the company's equity capital remained stable above 90 percent until the First World War. ${ }^{91}$ After the First World War, the managers of this Spanish firm used the huge profits gained during the war period to increase the company's capital and to accumulate equity reserves. Considering that, at the same time, profits started to decline - a trend that was to become permanent - this strategy led to the collapse of the company’s return on equity. ${ }^{92}$

\section{Figure 6: Sedó}

By looking at the data of the companies owned by the Sedó family it is easy to realise that their business strategy was far more conservative than the one implemented by La España Industrial. From 1884 to 1901, while the company was conformed as a general partnership under the name A. Sedó y Cía., a phase of profit growth derived into an almost immediate increment of the company's equity capital, consequently provoking the deterioration of the return on equity. This increase of the company's equity capital, based on a great expansion of the company's own capital from 2 to 5 million pesetas, was meant to finance the construction of the Cairat water reservoir and the introduction of new machinery. ${ }^{93}$

The gap between 1901 and 1902 is explained by the foundation of L.A. Sedó en Comandita, which represented a change in the legal form of the company. Between 1902 and 1936, the new company belonging to the Sedó family implemented the same strategy applied by its predecessors and maintained later on by the future company, Sedó S.A. It augmented the allocation of equity capital in the year following that on which profits increased. Sedó was among those companies that benefited the most from the First World War period, when it became an important supplier of corduroy, a fabric that was greatly in demand for the production of military uniforms. ${ }^{94}$ Once the euphoria around the world conflict was over, the company adjusted its balance sheet in 1924, cutting it down by 50 percent, something which caused a significant reduction of the company's 
equity capital. However, if considered proportionally, the company’s equity capital still represented 70 percent of its liabilities. ${ }^{95}$ When profits were consolidated in 1925, the company expanded its capital by 50 percent - as in previous occasions - in order to finance its investments in machinery and new installations as well as to cover the increasing needs of industrial and commercial current assets associated to the expansion of production. The right decision on investment was supported by the achievement of profits that were higher than the ones obtained before the war - those of the war period had an extraordinary character - and allowed, reaching a ratio of profitability over 10 percent between 1922 and 1935, doubling that of the pre-war period and exceeding the average of the different cotton enterprises (Table 2).

Figure 7 reflects the series of data corresponding to the different companies founded by the Valls family: Esteban Valls y Cía. (1878-1900), I. Valls i Pallerda (1900-1918), Valls i Mir en Comandita (1919-1920) and, finally, Manufacturas Valls S.A (1920). The first company created by Esteban Valls achieved one of the highest levels of profitability within the cotton sector (between ten and twenty percent) and, as in other firms, it reached a peak right before the final colonial insurrection. The succeeding company, Valls i Pallerda, launched a very important expansion of its equity capital in 1907, which, added to a phase of limited profit, led to a reduction in profitability. The former level of profitability was only recovered when the allocation of equity capital was reduced during the First World War period.

Figure 7. Valls

The data on Figure 7 do not include those of Valls i Mir en Comandita because of their exceptional character. This firm served as a bridge between the previous general partnerships belonging to the Valls family and the public limited company Manufacturas Valls S.A. In 1919 and 1920, the profitability of Valls i Mir en Comandita soared to 200 and 133 percent, respectively; including these data would totally distort the chart. In those years, profitability was boosted by the extraordinary profits, which reached, respectively, 750,000 and 532,000 pesetas. In 1920, the family founded Manufacturas Valls S.A. that still operated under the paradigm of the dynastic family 
business. This public limited company incorporated into its equity capital that of Valls i Pallerda, plus the profits generated by Valls i Mir. Standing on this base, in 1928 Manufacturas Valls S.A. launched an ambitious operation to expand its capital - it actually increased from 1.8 million pesetas that year to 5 million pesetas in 1930. The purpose was to finance the growth of the company's fixed assets and part of the current assets required after the increment of the company's activity.

\section{Conclusions}

This work contributes with a new perspective on Spanish cotton textile companies by showing how their behaviour was totally consistent with their nature. Their strategies and decisions were similar to those of their European counterparts, with no special differentiating features. There were no outstanding differences between dynastic (the majority) and non-dynastic (La España Industrial) companies, between unlimited liability firms and public limited companies, between companies that were quoted on the stock market (La España Industrial) and companies that were not (the rest of the public limited companies). Both European and Spanish family cotton companies shared the same objectives (longevity and family control) and implemented the same strategies based on organic growth, reinvestment of profits and overuse of their equity capital to finance fixed investment and much of the current assets required. They were all reluctant to external financing. If any, the difference between Spanish and other European companies may lie in the greater use of their equity capital on the part of the Spanish firms due to the country’s economic backwardness.

In the period that goes from 1884 to 1936, the financial decisions of Spanish cotton companies experienced no innovations whatsoever. Their short-term strategy was defined within the parameters of low indebtedness, the use of the family's patrimony to finance current assets and a high proportion of equity capital. A strategy that was labelled as "conservative” because it aimed to preserve the company and keep it under the control of the family. This strategy was certainly reinforced by the family's decision to increase the percentage of equity capital after each phase of profit growth. This behaviour was similar to that of other Spanish industrial companies, which, after 
achieving high profits during the First World War period, undertook "a not the least intense and sustained capitalisation process”. ${ }^{96}$

On the other hand, this work has intended to measure the cost of implementing this strategy. It was not the profits but the return on equity that suffered the most because of it. Spanish companies' profits improved during the brief period prior to the second Cuban insurrection, stagnated at the end of the century, when protectionist policies were firmly implemented in Spain, experienced a boom that lasted from the outbreak of the First World War to 1922 - a splendid year for most firms - and returned to pre-war levels during the second half of the 1920s and in the 1930s.

However, the analysis of the return on equity needs to go beyond the mere value of the ratio, because this indicator is conditioned by the amount of profits generated and by the evolution of the company’s equity capital. While profits depended greatly on the economic situation, equity capital evolved strictly according to the business strategy implemented. The owning families' decision to stand financially on their equity capital - in what regards both their fixed assets and an important percentage of their current assets - affected the behaviour of the return on equity in each of them. Thus, the traditional perspective that finds the causes for the companies' low profitability outside the firms' own functioning, in the overall bad economic circumstances, Spain's economic backwardness and the chronological sequence of political problems, needs to be diluted. It is true that the depressive situation at the end of the $19^{\text {th }}$ century and then again during the 1930 s led to a drop-off in profits, but it is also true that the progressive increment of the company's equity capital had an almost similar effect on the decrease of the return on equity. The families assumed the risk of sacrificing a high percentage of their potential profitability in order to secure the survival of their companies, reinforcing their conservative strategies as the economic-institutional context on which they operated grew increasingly unstable.

Three examples of the implementation of those business strategies have been provided in this article. All three of them show that the companies applied the same principles with just some 
minor discrepancies. Thus, La España Industrial, although quoted on the stock market, stayed within the typical parameters of all family firms in this sector and, in the 1920s and 1930s, heavily weighed down its profitability by increasing its equity capital at the same time the company's profits fell. Sedó and Valls were two faces of the same coin: both companies put all their hopes on their organic growth, something which handicapped their profitability, but while the former's profits remained stable, the latter's somehow increased.

The outcome was that Spanish cotton companies have survived under the control of the families that owned them from their foundation until the end of the $20^{\text {th }}$ century, covering the time span of four or five generations and, therefore, growing apart from the well-known and often mentioned "Buddenbrook syndrome”.

Finally, this article clarifies the traditional vision of Spanish specialised literature that underlined the importance of exogenous aspects associated to Spanish economic backwardness in determining the companies' behaviour. According to that approach, the companies’ strategy was not chosen freely. However, this article places the decisions of Spanish cotton companies on equal footing with those of their European counterparts, which, in spite of developing their activities within different economic and institutional frameworks, nevertheless implemented almost identical strategies. Generally speaking, it seems the behaviour of Spanish firms did not diverge from that of other European family businesses, except for the greater intensity in the use of the companies' equity capital in Spain. ${ }^{97}$ In other words, the family and mostly dynastic nature of both European and Spanish cotton textile companies - characterised by its low levels of transparency in what concerns the company's accounts and by its scale and scope externalities - weighed much more than all the exogenous factors related to Spanish economic backwardness when it came to choose the financial strategy of the firm. Exogenous factors intensified the companies' original features (the greater percentage of equity capital) but did not directly determine their strategy.

\section{Annexe 1. Ratio of indebtedness}

\section{Annexe 2. Ratio of indebtedness once the partners' accounts are deducted}




\section{REFERENCES}

Astrachan, M.C. and J.H. Shanker. “Family businesses' contribution to the U.S. economy: A closer look”. Family Business Review 9, no. 2, (2004): 107-123.

Benaul, J.Ma. "La comercialització dels teixits de llana en la cruïlla dels segles XVIII i XIX.

L’exemple de la fàbrica de Terrassa Anton i Joaquim Sagrera”. Arraona 13, (1993): 35-47.

Benaul, J.M․ “La llana”. In Història Econòmica de la Catalunya contemporània, vol. 5. Barcelona: Enciclopedia Catalana, 1998.

Boyson, R. The Ashworth Cotton Enterprise. Oxford: Clarendon Press, 1970.

Cabana, F. Fàbriques i empresaris: els protagonistes de la revolució industrial a Catalunya, Cotoners. Diputació de Barcelona: Barcelona, 1993.

Cabana, F. La burguesía catalana. Una aproximación histórica. Barcelona: Edicions Proa, 1996.

Cabana, F. Cien empresarios catalanes. Madrid: LID Editorial Empresarial, S.L., 2006.

Calvo, A. "La indústria cotonera catalana a conmençaments del segle XX”. Recerques 44, (2002): 91-110.

Casson, M. “The Economics of the Family Firm”. Scandinavian Economic History Review XLVII, no. 1, (1999): 10-23.

Chapman, S.D. "The Peels in the early English cotton industry”. Business History 11, (1969): 6189.

Chapman, S. Merchant enterprise in Britain. Cambridge: University Press, 1992.

Chapman, S.D. and S. Chassagne. European textile printers in the eighteenth century: a study of Peel and Oberkampf. London: Heinemann Educational, 1981.

Chandler, A. Scale and scope: the dynamics of industrial capitalism. Cambridge, Mass: Belknap, 1990.

Chandler, A. The visible hand: the managerial revolution in American business. Cambridge, Mass: Harvard University Press, 1977.

Colli, A. The History of family Business, 1850-2000. Cambridge: University Press, 2003. 
Colli, A. and M.B. Rose. "Families and firms: The Culture and Evolution of Family firms in Britain and Italy in the Nineteenth and Twentieth Centuries”. Scandinavian Economic History Review XLVII , no. 1, (1999): 24-47.

Colli, A., P. Fernandez Perez, and M.B. Rose. "National Determinants of Family Firm Development? Family Firms in Britain, Spain, and Italy in the Nineteenth and Twentieth centuries”. Enterprise \& Society 4, (2003): 28-64.

Daunton, M. "Inheritance and Succession in the City of London in the Nineteenth Century". Business History 30, (1988): 269-286.

Deu i Baigual, E. “L’esgotament del model del segle XIX. 1914-1939”. In Història Econòmica de la Catalunya contemporània, vol. 6. Barcelona: Enciclopedia Catalana, 1998.

Deu i Baigual, E. “Distribución de tejidos de lana catalanes en el mercado español, 1870-1935”. In Doctor J Nadal: la industrialización y el desarrollo económico de España. Barcelona: Universitat de Barcelona, 1999.

Deu i Baigual, E. "La comercialización de tejidos catalanes en Castilla-León y Cantabria, 18701914”. In Consumo, condiciones de vida y comercialización: Cataluña, Castilla, siglos XVII-XIX, ed. Torras, J. and B. Yun Casalilla. Ávila: Junta de Castilla y León, 1999.

Dorel-Ferré, G. Les colònies industrials a Catalunya: el cas de la Colònia Sedó. Montserrat: Abadía de Montserrat, 1992.

Dorel-Ferré, G. “Los orígenes del capital industrial catalán: el ejemplo de la familia Puig de Vilanova i la Geltrú”. Revista de Historia Industrial 8, (1995): 173-192.

Farnie, D. The English Cotton Industry and the world market, 1815-1896. Oxford: Clarendon Press, 1979.

Fernández Pérez, P. "Reinstalando la empresa familiar en la Economía y la Historia económica. Una aproximación a debates teóricos recientes”. Cuadernos de Economía y Dirección de Empresas 17, (2003): 45-66. 
Fernández, P. and A. Hernández. “The role of the State in the promotion of entrepreneurship among family business. The case of Spain in a long-run perspective”. Entrepreneurial History, Discussion paper, http://www.ehdp.net, 2010.

Fernández-Roca, J. Hytasa, 1937-1980. Diputación de Sevilla: Sevilla, 1998.

Fernández-Roca, J. “Beneficios e inversiones de una industria textil andaluza: Hytasa”. Revista de Historia Económica 3, (1998): 783-795.

Fernández-Roca, J. “The adaptative strategies of Spanish cotton industry companies, 1939-1970”. Business History 49, (2007): 75-97.

Ferrer, L. "El beneficio de los tejidos. La empresa Berenguer i Cia., de Artes, en la industrialización catalana”. Revista de Historia Industrial 39, (2009): 37-74.

Fitton, R-S. The Strutts and the Arkwrights, 1758-1830: a study of the early factory system. Manchester: University Press, 1958.

Handler, W.C. "Methodological Issues and Considerations in Studying family Business”. Family Business Review II, no. 3, (1989): 257-276.

Harrison, J. “Catalan goods and colonial markets, 1880-1914”. In King Cotton, a tribute to Douglas A. Farnie, ed. Wilson, J. Lancaster: Crucible Books, 2009.

Higgins, D. and S. Toms "Firm structure and financial perfomance: the Lancashire textile industry, c.1884-c.1960”. Accounting History Review 7, no. 2, (1997): 195-232.

Higgins, D. and S. Toms "Financial distress, corporate borrowing, and industrial decline: the Lancashire cotton spinning industry, 1918-1938”. Accounting, Business and Financial History 13, no. 2, (2003): 207-232.

Law, B.R. Fieldens of Todmorden. A Nineteenth century Business Dynasty. Littleborough (Lancashire): George Kelsall, 1995.

Lazonick, W. “Competition, Specialization and Industrial Decline”. Journal of Economic History XLI, no. 1, (1981): 31-39. 
Lazonick, W. "Industrial Organization and Technological Change: The Decline of the British Cotton Industry”. Business History Review 57, (1983): 195-236.

Licini, S. "Francesco Saverio Amman: An Austrian Cotton Entrepreneur in Lombardy, 1838-82”. Business History 41, (1999): 1-20.

Lloyd-Jones, R.; M.J. Lewis and M. Eason. “Culture as metaphor: Company Culture and Business Strategy at Raleigh Industries, c. 1945-60”. Business History 41, (1999): 93-133.

Maluquer de Motes, J. "La estructura del sector algodonero en Catalunya durante la primera etapa de la industrialización (1832-1861)”. Hacienda Pública Española, 38, (1976):133-148.

Maluquer de Motes, J. and J. Torras. “La formació d’una societat industrial”. In Història Econòmica de la Catalunya contemporània, vol. 1. Barcelona: Enciclopedia Catalana, 1998.

Mass, W. and W. Lazonick. “The British Cotton Industry and International Competitive Advantage: The State of the Debates”. Business History 32, (1990): 9-65.

Nadal, J. "Los Bonaplata, tres generaciones de industriales catalanes en la España del siglo XIX”. Revista de Historia Económica 1, (1983): 79-95.

Nadal, J. "La indústria cotonera”. In Història Econòmica de la Catalunya contemporània, vol. 3. Barcelona: Enciclopedia Catalana, 1998.

Nadal, J. and J. Fontana “España 1914-1970”. In Historia económica de Europa, coord. Cipolla, C.M., vol. 6. Barcelona: Ariel, 1980.

Nadal, J. and E. Ribas. “Una empresa cotonera catalana: la fábrica 'de la Rambla’, de Vilanova, 1841-1861”. Annales Cisalpines d'Historie Sociale 1, (1970).

Palafox, J. Atraso económico y democracia: la Segunda República y la economía española, 18921936. Barcelona: Crítica, 1991.

Parejo, A. “Sobre la segunda mayor empresa textil algodonera española: Industria Malagueña, S.A. (1882-1934)”. In Doctor J. Nadal: la industrialización y el desarrollo económico de España. Barcelona: Universitat de Barcelona, 1999. 
Prat, M. "Fabricar i comerciar a mitjan segle XIX. Dis casos dels Muntadas i els Batllori”. Recerques 47-48, (2003): 5-28.

Prat, M. "Los mayoristas de provincias en la comercialización de los tejidos catalanes (18501930)”. Revista de Historia Industrial 37, (2008): 155-178.

Prat, M. "Las estructuras comerciales de la industria algodonera catalana: el triunfo de los viajantes en el ultimo tercio del siglo XIX”. Investigaciones en Historia Económica 12, (2008): 79-110.

Prat, M. "Between the firm and the market: an international comparision of the commercial structures of the cotton industry (1820-1939)”. Business History 51, (2009): 181-201.

Prat, M.”Textile trade and trade credit in Spain, 1840-1913”. Financial History Review 16, (2009b): 73-94.

Ribas Mirangels, E. “La España Industrial (1851-1936). Análisis económico-financiero de la Compañía”. In Doctor J. Nadal: la industrialización y el desarrollo económico de España. Barcelona: Universitat de Barcelona, 1999.

Romano, R. L’industria cotoniera lombarda dall'unita al 1914. Milano: Banca Comerciale Italiana, 1992.

Rose, M.B. "The role of the family in providing capital and managerial talent in Samuel Greg and Company, 1784-1840”. Business History 1, (1977): 37-54.

Rose, M.B. The Gregs of Quarry Bank Mill. Cambridge: University Press, 1986.

Rose, M.B. "Beyond Buddenbrooks: The Family Firm and the Management of Succession in Nineteenth Century Britain”. In Entrepreneurship, Networks and Modern Business, Browm, J. and M.B. Rose. Manchester (N.Y.), 1993.

Rose, M.B. "The family firm in British business, 1780-1914”. In Business enterprise in modern Britain. Kirby, W. and M.B. Rose. London: Routledge, 1994.

Rose, M.B. The Lancashire Cotton Industry: A History Since 1700. Preston: Lancashire County Books, 1996. 
Rosés, J. “La integración vertical en el sector algodonero catalán, 1832-1861”. In ¿Que inventen ellos? Tecnología, empresa y cambio económico en la España contemporánea, eds., López, S. and J.M. Valdaliso. Madrid: Alianza Editorial, 1997.

Rosés, J. “The choice of Technology. Spanish, Italian, British and US cotton mills compared. 183060”. In The Mediterranean response to globalization before 1850, eds., Pamuck, S. and J.G. Williamson. London: Routledge, 2000.

Salini, A. "La società anonima Cotonificio Venzaghi di Busto Arsizio nei suoi primi trent'anni di attività (1906-1934)”. Annali di storia moderna e contemporanea 12, (2006): 177-201.

Scranton, P. Propietary capitalism. The textile manufacture at Philadelphia, 1800-1885. Cambridge: University Press, 1983.

Scranton, P. "Build a Firm, Start Another: The Bromleys and Family Firm Entrepreneurship in the Philadelphia Region”. Business History 35, (1993): 114-141.

Sharma, P. “An Overview of the Field of Family Business Studies: Current Status and Directions for the Future”. Family Business Review. XVII, (2004):1-36.

Solà, A. and B. Oliva. “Tejidos catalanes en el mercado andaluz en la segunda mitad del siglo XIX. La organización de las ventas en sociedad en comandita”. In Segundo Congreso de Historia Catalano-Andaluza: Cataluña y Andalucía en el siglo XIX. Relaciones económicas e intercambios culturales. Ed. Aquí y Multimedia S.L., 1997.

Soler, R. “Réditos algodoneros. Las cuentas de la fábrica de ‘la Rambla’ (1840-1914), revisión y ampliación”. Revista de Historia Industrial 12, (1997): 205-229.

Sudrià, C. "Desarrollo industrial y subdesarrollo bancario en Cataluña, 1844-1950". Investigaciones Económicas 18, (1982): 137-176.

Sudrià, C. "La exportación en el desarrollo de la industria algodonera española, 1875-1920". Revista de Historia Económica 2, (1983): 369-386.

Sudrià, C. "Una societat plenament industrial”. In Història Econòmica de la Catalunya contemporània, vol. 4. Barcelona: Enciclopedia Catalana, 1998. 
Sudrià, C. “La empresa española y los problemas de competitividad internacional. Una visión desde la industria algodonera”. In Las raíces históricas de los problemas actuales de la economía española. Madrid: Real Academia de Ciencias Morales y Políticas, 1999.

Tafunell, X. “Los beneficios empresariales en España, 1880-1981: Elaboración de una serie anual”. Madrid: Fundación Empresa Pública, (Programa de Historia Económica, nº 9601), 1996.

Tafunell, X. “Los beneficios empresariales en España, 1880-1981”. Revista de Historia Económica 3, (1998a): 707-746.

Tafunell, X. "Banca i mercat de capitals, 1866-1914”. In Història Econòmica de la Catalunya contemporània, vol. 3. Barcelona: Enciclopedia Catalana, 1998b.

Tafunell, X. "La rentabilidad financiera de la empresa española, 1880-1981: una estimación en perspectiva sectorial”. Revista de Historia Industrial 18, (2000): 71-111.

Toms, J.S. "Financial constraints on economic growth: profits, capital accumulation and the development of the Lancashire cotton-spinning industry, 1885-1914”. Accounting, Business and Financial History 4, no. 3, (1994): 363-383.

Toms, J.S. “Integration, Innovation, and the Progress of a Family Cotton Enterprise: Fielden Brothers Ltd., 1889-1914”. Textile History 27, no 1, (1996): 77-100.

Toms, J.S. "The Finance and Growth of the Lancashire Cotton Textile Industry, 1870-1914”. Business and Economic History 26, no. 2, (1997): 323-329.

Toms, J.S. "Windows of Opportunity in the Textile Industry: The Business Strategies of Lancashire Entrepreneurs, 1880-1914”. Business History 40, no. 1, (1998): 1-25.

Toms, J.S. “Growth, Profits and Technological Choice: The Case of the Lancashirte Cotton Textile Industry”. Journal of Industrial History 1, no 1, (1998): 35-55.

Toms, J.S. "Financial control, managerial control and accountability: evidence from the British Cotton Industry, 1700-2000”. Accounting, Organizations and Society 30, (2005): 627-653.

Toms, J.S. and J.F. Wilson. "Scale, Scope and Accountability: towards a new Paradigm of British Business History”. Business History 45, no 4, (2003): 1-23. 
Torres Villanueva, E. Los 100 empresarios españoles del siglo XX. Madrid: LID Editorial Empresarial, S.L., 2000

Westhead, P. and M. Cowling. "Family Firm Research: The Need for a Methodological Rethink”. Entrepreneurship Theory and Practice, Fall, (1998): 31-56.

\footnotetext{
${ }^{1}$ Benaul, “La llana”; Sudrià, "Una societat plenament industrial”; Maluquer and Torras, “La formació”; Nadal, "La indústria cotonera”; Deu, “L’esgotament”; Tafunell, “Banca i mercat”; Sudrià, “La empresa española”.

2 Toms, "Windows of Opportunity”. He reported on a similar situation in British historiography.

${ }^{3}$ Nadal and Ribas, "Una empresa cotonera”; Soler, "Réditos algodoneros”.

${ }^{4}$ See, for instance, Dorel-Ferré, Les colònies industrials; Ribas, “La España Industrial”; Parejo, “Sobre la segunda”. For the $20^{\text {th }}$ century, see Fernández-Roca, Hytasa; and “Beneficios e inversiones”.

5 Nadal, “Los Bonaplata”; Cabana, La burguesía catalana and Cien empresarios catalanes; Dorel-Ferré, "Los orígenes”; Torres, Los 100 empresarios españoles.

${ }^{6}$ Cabana, Fàbriques i empresaris.

${ }^{7}$ Ferrer, “El beneficio de los tejidos”.

${ }^{8}$ Prat, “Los mayoristas”; “Las estructuras comerciales”; “Between the firm” and “Textile trade”.

${ }^{9}$ Toms, “The Finance and Growth”, 328; Colli and Rose, "Families and firms”; Colli, et al. "National Determinants”; Fernández and Hernández, “The role of the State”, 9.

${ }^{10}$ The Chandlerian conception reduced family firms to a series of negative features: medium or small size, "organic” development (through reinvestment of profits), infrequent use of financial and capital markets (circumscribed to shortterm commercial financing), internal succession in management positions according to inheritance laws, lack of capacity to support modern economic growth (Chandler, Scale and scope and The visible hand; Lazonick, “Competition, Specialization” and “Industrial Organization”; Mass and Lazonick, “The British Cotton Industry”).

${ }^{11}$ Nadal, “La indústria cotonera”. Between 1878 and 1913, the growth of the Spanish cotton industry can be measured by the evolution in the number of spindles, which rose from 1.75 million to 2 millions (a maximum was reached in 1901 with 2.64 million spindles). Calvo, “La indústria cotonera”.

${ }^{12}$ Calvo, “La indústria cotonera”.

13 “Practically all the mills are owned by private companies, usually composed of one or two families.” (Ralph M. Odell, U.S. Department of Commerce and Labor, quoted by Harrison, “Catalan goods and colonial”, 169. Higgins and Toms, “Firm structure”, 204.
} 
${ }^{14}$ Without being exhaustive: Sharma, “An Overview of the Field”; Handler, "Methodological Issues”; Westhead and Cowling, "Family Firm Research”; Astrachan and Shanker, “Family businesses”.

${ }^{15}$ Colli and Rose, "Families and firms”, 194.

${ }^{16}$ Casson, "The Economics of the Family Firm”.

${ }^{17}$ Cabana, Fàbriques $i$ empresaris, in his description of Spanish cotton companies, provides a catalogue of their characteristics, which coincide with those of dynastic family companies. See Fernández Roca, “The adaptative strategies", on the second half of the $20^{\text {th }}$ century.

18 “'One frequently finds them operating under the name of 'The Widow of -', 'The Brother of -', 'The Nephew of -', etc.” (Ralph M. Odell, U.S. Department of Commerce and Labor, quoted by Harrison, “Catalan goods”, 169).

${ }^{19}$ Lloyd-Jones, et al. "Culture as metaphor”. The difficulties and potential conflicts associated to the intergenerational change are well analysed in specialised literature: Daunton, “Inheritance and Succession”; Rose, "Beyond Buddenbrooks”; Scranton, Propietary capitalism; Colli, et al. “National Determinants”; Fernández Pérez, “Reinstalando la empresa familiar”.

${ }^{20}$ Toms, “Windows of Opportunity”, 3.

${ }^{21}$ Rose, “The family firm in British”.

${ }^{22}$ Nadal, “La indústria cotonera”, 69-72; Sudrià, “La empresa española”. This situation was even more evident in the wool industry: Benaul, “La comercialització”; Deu, “Distribución de tejidos” and "La comercialización de tejidos”; Sudrià, "Desarrollo industrial y subdesarrollo”; Solà and Oliva, “Tejidos catalanes”.

${ }^{23}$ Ferrer, “El beneficio de los tejidos”, 59.

${ }^{24}$ Prat, "Fabricar i comerciar"; "Los mayoristas”; "Las estructuras comerciales”; "Between the firm” and "Textile trade”.

${ }^{25}$ On the commercialisation of the British cotton production, see Chapman, Merchant enterprise.

${ }^{26}$ Rosés, “La integración vertical” and “The choice of Technology”; Prat, "Fabricar i comerciar” and "Las estructuras comerciales”.

${ }^{27}$ Prat, “Between the firm”.

${ }^{28}$ Nadal, “La indústria cotonera”, 45.

${ }^{29}$ See Cabana, Fàbriques i empresaris, 97.

${ }^{30}$ Toms ("Integration, Innovation”, 95-96) stated that the Fieldens managed Fielden Brothers Ltd. to the benefit of the family.

${ }^{31}$ In this sense, the difference with the Oldham companies (Osborne or Werneth) was great. The managers of those firms, either in their own interest (a part of their retribution came from the distribution of dividends) or pushed by the 
shareholders, preferred to maximise the distribution of dividends even if it entailed the decapitalisation of the company (Toms, "Financial constraints”).

${ }^{32}$ This was not always so. There were companies as, for instance, Ashworth that distributed their assets among the members of the family (Boyson, The Ashworth).

${ }^{33}$ Toms, “The Finance and Growth”, 324. He stated that “capital growth rates were strongest where private or family control was exercised and weakest where there was a dependency on regional stock markets”.

${ }^{34}$ Rose, “The role of the family”; Colli, The History; Colli, et al. "National Determinants”, 35-36. A company’s legal form was determined by a "complex array of legal, economic and cultural forces”, Rose, “The family firm in British”, 64.

${ }^{35}$ Nadal, "La indústria cotonera”, 43. However, the number of limited partnerships slowly increased because this legal form allowed to collect an important amount of capital with minimum transaction costs and to easily connect capital suppliers and capital demanders. Tafunell, "Banca i mercat”, 418.

${ }^{36}$ Farnie (The English Cotton Industry, 220) showed how joint-stock companies were created in Lancashire in three different phases during the last third of the $19^{\text {th }}$ century: $1873-1875,1880-1884$ and $1889-1892$. During the $19^{\text {th }}$ century, public limited companies were rarely constituted within the Spanish cotton industry, except between 1847 and 1855, when six of them were founded: La España Industrial (1847), La Fabril Cotonera (1852), La Cotonera (1853), La Industrial Cotonera (1853), La Igualadina Cotonera (1853), La Manufacturera de Cotó (1855). The following one, Sucesora de Fabra i Portabella S.A., was not created until 1884, after a long period during which the process was paralysed. (Cabana, Fàbriques i empresaris, 81).

${ }^{37}$ Fernández and Hernández, “The role of the State”, 9.

${ }^{38}$ In the case of Venzaghi, 85 percent of the capital was in the hands of the family (Salini, "La società anonima”, 181). Fielden Brothers Ltd. remained a family firm even when it became a public limited company (Law, Fieldens of Todmorden: 236-249 and 271-277; Toms, (“Integration, Innovation”).

${ }^{39}$ Cabana, Fàbriques i empresaris, La burguesía catalana and Cien empresarios catalanes; Fernández-Roca, “The adaptative strategies”.

${ }^{40}$ Toms and Wilson, “Scale, Scope”, 11.

${ }^{41}$ Mass and Lazonick, "The British Cotton Industry"; Toms and Wilson, "Scale, Scope”; Cabana, Fàbriques i empresaris; La burguesía catalana and Cien empresarios catalanes.

${ }^{42}$ Cabana, Fàbriques i empresaris; Ribas, "La España Industrial”.

${ }^{43}$ Nadal and Ribas, “Una empresa cotonera”; Soler, “Réditos algodoneros”.

${ }^{44}$ Ferrer, "El beneficio de los tejidos". 
${ }^{45}$ Hilaturas Forcada: fons 199: 07.01.03.03 and. 07.01.03.04;

Sedó: fons 146: 05.02.07.01 to 0.02.07.10;

Fabra: fons 716: 07.01.03.01;

Valls: fons 195: 07.01.01.11, 07.01.01.12; 07.01.02.03 to 07.01.02.06;

Viladomiu: fons 192: 07.01.03.01 to 07.01.03.13;

Mata: fons 368: 07.01.03.71;

Serra i Feliu: fons 358: 07.01.03.109 to 07.01.03.113;

Almeda: fons 19: 07.01.03.

${ }^{46}$ Arxiu Comarcal Baix Llobregat: Güell, fons ACBL50-103.

${ }^{47}$ A similar list is found in Toms, "Windows of Opportunity".

${ }^{48}$ Toms ("Windows of Opportunity") uses an indicator which is similar to the ratio of equity capital: the capital accumulation rate (the increase in the capital employed, defined as the balance sheet total of share capital, shareholders' reserves and long-term loan capital).

${ }^{49}$ Indebtedness is also a relevant ratio for Higgins and Toms, "Financial distress".

${ }^{50}$ Toms (“Financial constraints”; “Integration, Innovation”; “The Finance and Growth”; “Windows of Opportunity”) and Higgins and Toms ("Firm structure") use ROCE (return on capital employed) because they intend to measure the return on productive investment and aim to find the relation between business strategies, on the one side, and economic growth, technological change, productive innovation and the existence or absence of vertical integration, on the other. Although ROCE and return on equity are not at all identical, the latter is the only available ratio allowing us to compare Spanish and British companies.

${ }^{51}$ Net distributable profits are used by Tafunell in his national series ("Los beneficios empresariales”; "Los beneficios empresariales en España”; “La rentabilidad financiera”). Nadal and Ribas (“Una empresa cotonera”), Soler (“Réditos algodoneros”), Dorel-Ferré (Les colònies Industrials), Ribas (“La España Industrial”), Parejo (“Sobre la segunda”), calculate the return on equity of the factories under study because the sources that are available only provide data on their net distributable profits.

${ }^{52}$ On Berenguer, see Ferrer, "El beneficio de los tejidos". This situation was also common at La Rambla (Soler, “Réditos algodoneros”).

${ }^{53}$ Ribas, “La España Industrial”, 1137.

${ }^{54}$ Rose, “The role of the family”; Champham and Chassagne, European textile printers; Law, Fieldens of Todmorden; Licini, “Francesco Saverio Amman”; Salini, “La società anonima”; Sudriá, “Una societat plenament industrial”, 60. 
${ }^{55}$ During the $19^{\text {th }}$ century, Oberkampf's equity capital oscillated between 52 and 83 percent (Chapman and Chassagene, European textile printers). Between 1865 and 1889, as Tordmorden Spinning, the Fieldens accounted for 100 percent of their assets (freehold property, machinery and working capital) with their capital employed. And in 1913, already as Fielden Brothers Ltd., 100 percent of their assets were backed by their share capital (up to 72 percent of them) and by retained earnings and other resources (the remaining 28 percent) (Law, Fieldens of Todmorden, 129, 245). Farnie’s data (The English Cotton Industry) on the Oldham Limiteds (around 100 companies) indicate that their equity capital ranged between 45 and 60 percent for the period between 1877 and 1896. But although the Oldham Limiteds were public limited companies that reduced their percentage of capital employed, this did not fall below 55 percent between 1885 and 1913 (Toms, "Financial constraints”, 372). In Italy, Venzaghi (Salini, “La società anonima”) and Amman (Licini, "Francesco Saverio Amman”) also fit into the general pattern. On the financing of clients by Spanish cotton companies see Nadal, “La indústria cotonera”; Sudriá, “La empresa española”; Ferrer, “El beneficio de los tejidos”; Prat, "Between the firm" and "Textile trade".

${ }^{56}$ Prat, “Textile trade”, 82-83.

${ }^{57}$ Samuel Greg and Co. applied for long-term loans only a couple of times between 1784 and 1840 (Rose, "The role of the family”, 37). The Fielden family financed the current assets of its factories in Todmorden with its own money (Law, Fieldens of Todmorden). Peel and Oberkampf behaved in a similar way (Chapman and Chassagne, European textile printers). The companies used as examples by Toms ("Windows of Opportunity”) were also reluctant to ask for bank loans and resorted to their social networks to meet their financing needs. In this sense, there are no relevant differences with Amman or Venzaghi (Licini, “Francesco Saverio Amman”; Salini, “La società anonima Cotonificio”).

${ }^{58}$ Sudrià, “Una societat plenament industrial”, 61.

${ }^{59}$ Tafunell, "Banca i mercat”.

${ }^{60}$ Serra's ratio of indebtedness once the partners' accounts were deducted was 0.02, while Almeda (0.3), Berenguer (0.05) and Sedó (0.34) reconfirmed the hypothesis. Annexe 2.

61 Sudrià, “Una societat plenament industrial”, 31; "La exportación”.

${ }^{62}$ Deu, “L'esgotament”.

63 Nadal and Fontana, “España 1914-1970”; Deu, “L’esgotament”.

${ }^{64}$ For instance, equity capital in Forcada experienced a 41 percent decrease in 1918, while Sedó's were reduced by 31 percent and Viladomiu's by 38 percent in 1919. In 1920, Valls' equity capital declined by 23 percent and Güell's by 33 percent. Business balance sheets. Own elaboration.

${ }^{65}$ Annexe 1.

${ }^{66}$ Annexe 2 . 
${ }^{67}$ On the investments made by the cotton industrial sector, see Calvo, "La indústria cotonera”; Sudrià, "Una societat plenament industrial”; Deu, “L’esgotament”. For British companies, see Toms, “Financial constraints”; “Integration, Innovation”; “The Finance and Growth”; "Windows of Opportunity”; Higgins and Toms, "Firm structure”; "Financial distress".

${ }^{68}$ Nadal, “La indústria cotonera”, 77.

${ }^{69}$ Ribas, “La España Industrial”, 1132.

${ }^{70}$ Ferrer, “El beneficio de los tejidos”.

${ }^{71}$ That was also the case of Samuel Greg and Co. or Venzaghi, whose growth was based on the reinvestment of profits (Rose, “The role of the family”; Salini, “La società anonima”, 184-185).

${ }^{72}$ Ribas (“La España Industrial”, 1132) concluded that, in the case of La España Industrial, that investment in cotton industry resulted in very low profitability.

${ }^{73}$ Nadal, “La indústria cotonera”, 47.

${ }^{74}$ The profits of Fielden (Law, Fieldens of Todmorden, chapters 7 and 8) or Venzaghi (Salini, “La società anonima”, 185) evolved quite similarly to those of the Spanish companies.

${ }^{75}$ Maluquer and Torras, “La formació”, 230-231.

${ }^{76}$ See the Ley de Relaciones Comerciales con nuestras Provincias de Ultramar (Act of Commercial Relations with the Overseas Provinces, 1882) and the Cánovas Tariff (1891) in Nadal, “La indústria cotonera”. 61 ff.; Harrison, “Catalan goods”; Maluquer and Torras, “La formació”.

77 Deu, “L’esgotament”, 13-14; Maluquer and Torras, “La formació”; Harrison, “Catalan goods”.

78 Sudrià, “Una societat plenament industrial”, 57; Deu, “L’esgotament”.

79 Profits in the wool sector behaved similarly to those in the cotton sector. Deu, "L'esgotament”; Sudrià, “La exportación”.

80 Deu, “L’esgotament”.

81 Specialised literature does not clarify the effects of the Cambó Tariff on the hegemonic Catalan textile companies. Sudrià ("Una societat plenament industrial”) states that these companies were not particularly favoured by the tariff due to the already existing high level of protection. On the contrary, Deu (“L'esgotament”) argues that protectionism was the only way out for the Catalan industry in order to overcome the crisis that affected the companies once the period of prosperity associated to the First World War was over. He also states that Catalan businessmen were especially active in supporting the strengthening of commercial protectionism.

${ }^{82}$ Deu, “L’esgotament”, 37.

${ }^{83}$ Nadal and Fontana, “España 1914-1970”; Palafox, Atraso económico; Deu, “L’esgotament”. 
${ }^{84}$ Tafunell (“La rentabilidad financiera”) states that consumption goods industries suffered a severe crisis until the 1890s, followed by a period of prosperity at the turn of the century. The difference between some industries and others lies in their evolution during those years, as well as in the boom experienced by the Oldham Limiteds between 1904 and 1910. Toms, “Financial constraints”.

85 In Japan, the accumulation of reserves after the war allowed the companies to survive the boom and slump of the 1920s. Higgins and Toms, “Financial distress”, 211.

86 Toms, “Integration, Innovation”; “Windows of Opportunity”; “Growth, Profits”; Law, Fieldens of Todmorden; Salini, “La società anonima”; Licini, “Francesco Saverio Amman”.

87 See the data on British companies in Higgins \& Toms, “Firm structure”, 209; Toms, “Windows of Opportunity”, 5.

88 Cabana, Fàbriques i empresaris.

89 Fielden Brothers Ltd. could be classified as a non-dynastic family firm, considering its characteristics as described by Toms, “Integration, Innovation”.

90 Toms, “Financial constraints”, 369-371.

91 Between 1847 and 1861, La España Industrial distributed a high percentage of its profits among its shareholders in order to maintain the value of its shares - and this brought the company to a delicate financial situation. Nadal, "La indústria cotonera”, 47.

92 Between 1931 and 1935 the factory at Sants was enlarged and two smaller companies, Filats Mohair and Vda. de Ricard Sada, were taken over. Cabana, Fàbriques i empresaris, 112.

93 Nadal, “La indústria cotonera”, 77.

94 The French army did not question the product's quality and price; it was only worried about the delivery of the material. The dialogue between the manufacturer and a general of the French army can illustrate the situation. Whenever delivery times were too short, the Sedó family raised the product's final price and justified this action by mentioning the need to speed up production: "Procurarem fer-li el que ens demana, pero no podem donar cap garantia sobre la qualitat del producte final" ("We will try to do what you require, but we cannot guarantee the quality of the final product”) said the family, and the French general's answer was "no es preocupin per la qualitat. El soldat que porti aquest uniforme estara mort abans que esfaci malbe la tela” (“Do not worry about quality. The soldier wearing that uniform will be dead long before the tissue is worn out.”). Cabana, Fàbriques i empresaris, 292.

95 The behaviour of the Sedó family company was the opposite of that of the firms described by Higgins and Toms, “Financial distress”.

96 Tafunell (2000). 
${ }^{97}$ Toms (“The Finance and Growth”; “Growth, Profits”) stated that he missed an international framework against which British companies could be compared. On these European companies see: Greg (Rose, "The role of family"; The Gregs), Strutts (Fitton and Wadsworth, The Strutts), Peel (Chapman, “The Peels”), Peel and Oberkampf (Chapman and Chassagne, European textile), Ashworth (Boyson, The Ashworth), Fielden (Law, Fielden of Todmorden; Toms, “integration, Innovation”), Caprotti (Romano, L’industria cotoniera), Venzaghi (Salini, “La società anonima”), Amman (Licini, “Francesco Saverio Amman). 